DIW BERLIN

Discussion

Papers
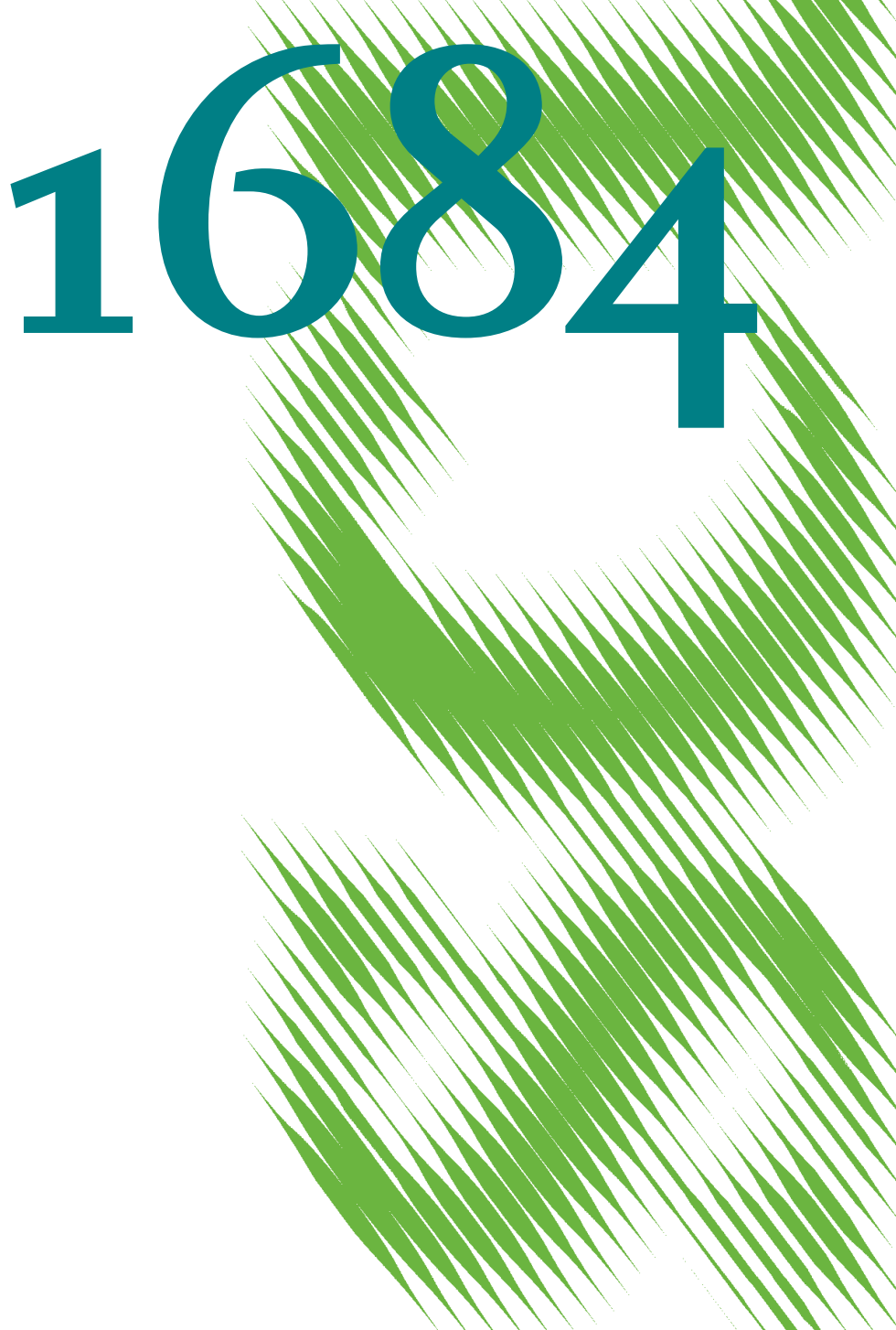

Financing Power: Impacts of Energy Policies in Changing Regulatory Environments 
Opinions expressed in this paper are those of the author(s) and do not necessarily reflect views of the institute.

IMPRESSUM

(C) DIW Berlin, 2017

DIW Berlin

German Institute for Economic Research

Mohrenstr. 58

10117 Berlin

Tel. +49 (30) $89789-0$

Fax +49 (30) $89789-200$

http://www.diw.de

ISSN electronic edition 1619-4535

Papers can be downloaded free of charge from the DIW Berlin website:

http://www.diw.de/discussionpapers

Discussion Papers of DIW Berlin are indexed in RePEc and SSRN:

http://ideas.repec.org/s/diw/diwwpp.html

http://www.ssrn.com/link/DIW-Berlin-German-Inst-Econ-Res.html 


\title{
Financing Power: Impacts of Energy Policies in Changing Regulatory Environments
}

\author{
Nils May, Karsten Neuhoff ${ }^{\dagger}$
}

September 26, 2017

\begin{abstract}
Power systems with increasing shares of wind and solar power generation have higher capital and lower operational costs than traditional technologies. This increases the importance of the cost of finance for total system cost. We quantify how renewable policy design can influence cost of finance by addressing regulatory risk and facilitating hedging. We use interview data on wind power financing costs from the EU and model how long-term contracts signed between project developers and energy suppliers impact financing costs in the context of green certificate schemes. Between the policy regimes, the cost of renewable energy deployment differ by $30 \%$.
\end{abstract}

Key words: Investments; Long-term contracts; Financing costs; Liberalization of power markets; Renewable energy policies.

JEL classification: Q42, Q55, O38

\footnotetext{
* Corresponding author. Climate Policy Department, German Institute for Economic Research Berlin (DIW Berlin), Mohrenstrasse 58, 10117 Berlin, Germany. Email: nmay@diw.de

${ }^{\dagger}$ Climate Policy Department, German Institute for Economic Research Berlin (DIW Berlin), Mohrenstrasse 58, 10117 Berlin, Germany and Technical University (TU) Berlin, Faculty of Economics and Management.
} 


\section{Introduction}

The rising share of capital-intensive assets increases the importance of financing costs for the total costs in power systems. This holds particularly true for renewable energies as opposed to coal and gas power plants, where the costs of renewable energy deployment are to a large extent driven by the capital costs at which investors finance these projects. Bloomberg New Energy Finance (2016) estimates investments of $\$ 7.3$ trillion into wind and solar power between 2017 and 2040, and a further $\$ 5.3$ trillion in order to stay within two degrees of global warming. These investments strongly depend on access to low-cost financing.

The financing costs depend on the risks faced by investors, which hinge on the regulatory framework. On the one hand, regulation impacts the mere risk allocation, for example regarding project performance, which is usually best left with investors to avoid adverse incentives. On the other hand, the regulatory framework can also induce risks, for instance linked to uncertain policy developments, or it can eliminate risks, e.g. by facilitating contracts between parties with complementary exposure. The regulatory regime can have two main impacts on financing risks; Regulatory risks and market risks.

First, regulatory risks arise due to uncertainty about future revenues from support policies like premium payments, quotas or off-take guarantees through feed-in tariffs. This policy design may shift regulatory risk between parties, but where policy risk can be avoided altogether, policies can reduce rather than shift overall deployment costs.

Second, market risks are introduced where support mechanisms do not comprise explicit off-take guarantees or some structure of contract for difference to secure the price on energy revenues. Investors then typically sign bilateral long-term contracts to secure these revenue streams. As Newbery (2016) argues, some forms of long-term contracts between generators and retailers are required to hedge against these market risks and to provide investors with sufficient certainty about their future cash flows. Discussing investments into peakgenerators, Joskow (2006) analyzes how the lack of long-term contracts does not necessarily deter investments, but increases financing costs. Both producers and consumers are risk averse, and therefore prefer a stable price over an uncertain price. However, under liberalized power markets, private and usually also industrial consumers do not sign contracts for durations exceeding a few years. This may reflect constraints on switching time-frames (or compensation payments), counterparty risks that are difficult to hedge, and asymmetric information about what would be a competitive price.

We quantify how far the regulatory and market risks under different renewable energy policies affect the overall deployment costs. To this end, we first analyze in how far regulatory risks under feed-in tariffs, sliding feed-in premia and tradable green certificates translate into higher financing costs for renewable energy investors. We test this with a unique dataset on wind power financing cost estimates for which investors, bankers, academics and utilities provide estimates of the weighted average costs of capital in the EU. Second, we analyze the effects of market risks on long-term contracts analytically when policies do not provide explicit or implicit off-take guarantees. We find structural reasons that the price renewable investors receive for long-term contracts is below the expected value, reflecting increased financing costs incurred by their counterparties when engaging in such contracts. 
Overall, our results indicate that policy design can change the level of financing costs by about 4.8 percentage points overall, comparing fixed feed-in tariffs with green certificate schemes, which is equivalent to a change in the costs of renewable energy deployment of about 29 percent. The change in costs is a result of on the one hand reducing regulatory risk, and on the other hand eliminating market-related risks by facilitating implicit hedging between producers and consumers.

The remainder of this paper is structured as follows: After an overview over policies supporting renewable energy in section 2, we estimate policy impacts on investors' financing costs in section 3. Section 4 analyzes how incomplete long-term contracts incur additional costs for off-takers. The paper ends with a conclusion.

\section{Investments into renewable energy}

Three main policies to support renewable energy investments dominate globally: Fixed feed-in tariffs (FIT), sliding feed-in premia (FIP) and tradable green certificates (TGC) ${ }^{1}$. In 2015, feed-in tariffs or feed-in premia existed in 75 countries, whereas tradable green certificates were in place in 26 countries and many states of the US (REN21, 2016). ${ }^{2}$

Price-based support policies like feed-in tariffs and sliding feed-in premia provide investors with a certain remuneration level. Under feed-in tariffs, the regulator takes off the electricity output and guarantees a remuneration level, such that operators face no uncertainty with respect to remuneration per $\mathrm{kWh}$. Under feed-in premia, investors sell their output to private off-takers, and receive an additional sliding premium, where the sum of the two elements on average across all installations equals the feed-in tariff remuneration. For any individual plant, there is some uncertainty with respect to the total remuneration due to deviations from average production patterns (May, 2017), and additional balancing costs or changes of price zones can induce risks (Tisdale et al., 2014), leading e.g. Couture and Gagnon (2010) to argue based on theoretical arguments that feed-in premia entail risk premia as compared to feed-in tariffs. Yet, so far Klobasa et al. (2013) find no significant changes in investment conditions when analyzing descriptive statistics of the German experience after a shift in 2012 from a feed-in tariff to a sliding premium, and Kitzing (2014) goes as far as classifying feed-in tariffs and sliding feed-in premia as one, merely distinguishing higher risk fixed feed-in premia.

Tradable green certificates constitute quantity-based instruments where investors sell their electricity output to private counterparties, and further receive green certificates proportional to their output. Retail companies are obliged to obtain for such certificates, creating demand for them, and hence establishing a revenue stream for renewable energy operators additional to the sale of electricity.

\footnotetext{
${ }^{1}$ Alternative names for FIPs are Market Premium and Contracts for Differences, with the main difference that under Contracts for Differences, the contractual obligation goes both ways, such that the premium can basically be negative, shielding consumers from high prices. TGC also run as Renewable Portfolio Standards or Green Quotas.

${ }^{2}$ Since sliding feed-in premia dominate fixed feed-in premia globally, we discuss only sliding feed-in premia.
} 
Many authors have raised concerns that under real world conditions, green certificates induce additional investment risks. Butler and Neuhoff (2008) analyze the British green certificate scheme and the German feed-in tariff and find that when correcting for the countries' different wind resources, the German system has been more successful, in the sense that it has managed to trigger considerably more investments at lower cost to consumers. Similarly, Haas et al. (2011) scrutinize descriptive statistics on installation numbers and general remuneration costs for a small number of European countries and find that feed-in tariffs have been more successful in both respects. In line, Bürer and Wüstenhagen (2009) conduct a survey among investors and show, using a stated preferences approach, that these prefer feed-in tariffs over green certificates. A survey of British investors suggests that the expected risk premium of the green certificates compared to the newly-introduced feed-in premium amounts to 0.81.7 percentage points (NERA, 2013).

Yet, some authors also argue in favor of the efficiency of quantity instruments. Applying a real options investment model, Boomsma and Linnerud (2015) argue that investment incentives do not differ strongly between green certificates and feed-in tariffs and additional risk premia under green certificates are small. Schmalensee (2012) argues that social costs under feed-in tariffs are higher due to the unknown installation quantities.

However, the studies on the financing cost impacts of these policies are based on theoretical assessments or on case studies for only very few countries. Analyzing a survey on wind power financing costs in 23 European countries, we contribute to the literature by providing empirical evidence on differences in financing costs between countries with different policies.

\section{Estimating investors' financing costs}

Renewable energy support schemes expose investors to regulatory risks to a varying degree. We test the effects on financing costs with interview data on the financing costs of wind power projects from the EU. We estimate in how far wind power policies can be associated with higher risk premia for wind power investors.

The risk premium is the difference between weighted average cost of capital (WACC) and a country's specific risk-free rate $\gamma_{c}$.

$$
\text { risk premium }=W A C C-\gamma_{c}
$$

\subsection{Data}

For the analysis, we deploy interview data of financing cost estimates by project developers, bankers and academics from 23 EU countries. ${ }^{3}$ Table 1 provides descriptive statistics for the variables.

The financing costs are represented by the weighted average costs of capital, which reflect the costs of both equity and debt. Equity naturally has higher required returns than debt. The respective ratio between the two variables matters: higher shares of equity lead to higher weighted average cost of capital

\footnotetext{
${ }^{3}$ We have no data for Luxembourg, Malta, Portugal and Slovenia. As explained in the following, we exclude Estonia due to its very particular FIT implementation.
} 
Table 1: Descriptive statistics

\begin{tabular}{llllll}
\hline Variable & N & Mean & Std. dev. & Min. & Max. \\
\hline WACC & 53 & 8.22 & 2.81 & 2.5 & 13.5 \\
WACC approximated $\dagger$ & 53 & 8.30 & 2.92 & 2.5 & 15 \\
Avg gvt. bond yields 01/14 & 53 & 3.73 & 2.53 & 1.59 & 9.81 \\
Risk premium approximated $\ddagger$ & 53 & 4.57 & 1.43 & 0.73 & 7.25 \\
\hline Feed-in tariff & 53 & 0.57 & 0.50 & 0 & 1 \\
Sliding feed-in premium & 53 & 0.23 & 0.42 & 0 & 1 \\
TGC w. price floor & 53 & 0.15 & 0.36 & 0 & 1 \\
TGC w/o price floor & 53 & 0.06 & 0.23 & 0 & 1 \\
\hline Tenders & 53 & 0.08 & 0.27 & 0 & 1 \\
Retroactive changes conducted & 53 & 0.25 & 0.43 & 0 & 1 \\
No policy in place & 53 & 0.19 & 0.39 & 0 & 1 \\
\hline Consultant/Academic & 53 & 0.32 & 0.47 & 0 & 1 \\
Equity investor & 53 & 0.34 & 0.48 & 0 & 1 \\
Utility employee & 53 & 0.17 & 0.38 & 0 & 1 \\
Banker & 53 & 0.17 & 0.38 & 0 & 1 \\
\hline
\end{tabular}

Note: The policy dummies for feed-in tariff, sliding feed-in premium, TGC with price-floor and TGC without price floor are mutually exclusive. The same holds for the investor types consultant/academic, equity investor, utility employee and banker. $\dagger$ †or relative responses, "slightly higher" was treated as 0.5 percentage points higher, "higher" as 1.0 percentage point, and "much higher" as 1.5 percentage points łapproximated WACC minus average government bond yields

estimates. Details on the data and the interviews can be found in Diacore (2015).

We obtain the wind power risk premium by subtracting the risk-free rate from the weighted average cost of capital. This risk-free rate is commonly approximated by the yield on long-term government bonds, as it represents the varying country risks due to general political and financial contexts. At close to 10 percent, Greek bonds ranked the highest, followed by Cypriot and Portuguese ones, based on Eurostat (2017). At the lower end, the bonds of Germany, Denmark and Finland paid the lowest returns with less than two percent. ${ }^{4}$ Since the interviews were conducted in spring 2014, we approximate the country risk with the average yield in the six months before and after the beginning of 2014, i.e. 07/2013-06/2014.

Based on Res Legal (2014) and González and Arántegui (2015), we identify whether a feed-in tariffs, sliding feed-in premia or green certificate schemes prevailed in early 2014 in the EU countries (see figure 1). When support varied with project size, we classify the country using the policy for larger installations, as project developers are more likely to be involved in larger settings.

\footnotetext{
${ }^{4}$ We also tested using official Eurostat data on firm lending rates. Yet, we deemed the data unreliable, as in 2013 and 2014, lending rates for Spanish, Italian and Greek firms seemed unrealistically low, i.e. lower than for example the lending rate of British firms. Additionally, the resulting risk premium for renewable projects was partially negative, additionally casting doubts on this dataset's reliability.
} 


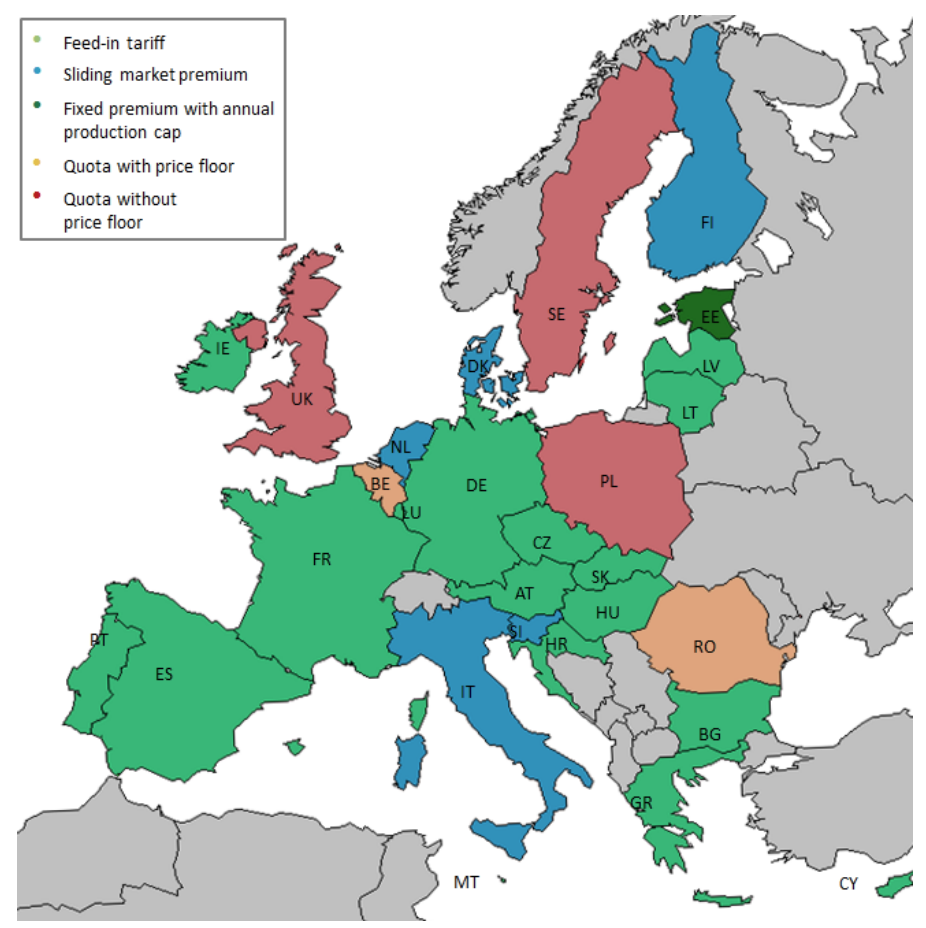

Figure 1: Onshore wind power policies in the EU in spring 2014. Source: Res Legal (2014) and González and Arántegui (2015)

Several countries had particular policy implementations which distinguish their schemes from those of other countries. In Germany, investors could choose between a feed-in tariff and a feed-in premium in early 2014. Diverging from Klobasa et al. (2013), we evaluate this as a feed-in tariff, since investors were always able to choose the safe feed-in tariff. Estonia defines an annual limit of remunerated GWh. Once this limit is reached, no further remuneration is paid, as occurred in 2015 , when about $13 \%$ of production did not receive any support (Estonian Windpower Association, 2015). This mechanism introduces significant revenue risks for operators and seems not comparable to the usual policies, such that we drop the Estonian observations (which show indeed very high risk premia). The Belgian regions and Romania run green certificate schemes. However, price minima provide absolute safety against lower returns, similar to feed-in tariffs. Thus, we count their policies as feed-in tariffs. For sensitivity analyses, we drop this assumption and include them as separate class of policy scheme. Only Denmark employed a fixed feed-in premium. However, its payouts partially resemble sliding premia, as total remuneration is capped, similar to a strike price under sliding premia. Treating Denmark explicitly as having a fixed feed-in premium does not influence the results in the following, such that we generally simply include it in the group of countries with sliding feed-in premia. Czech Republic, Spain and Latvia had implicitly abandoned any remuneration for new projects, if not explicitly. Only Italy used tenders for large-scale wind power projects at that time.

In the interview data, we furthermore have information on whether respon- 
dents think that retrospective cuts were conducted in their countries. Moreover, we know the investor type, with roughly a third of both consultants/academics and equity investors, and about a sixth of both utility employees and bankers.

\subsection{Estimation strategy}

We aim to estimate the effect of wind power policies on the wind power risk premium, i.e. the weighted average cost of capital minus the risk-free rate, estimated as shown in equation 16. Importantly, our key explanatory variable whose effect we aim to assess is the policy scheme. Its coefficients are $\beta_{1}$ for sliding feed-in premia and $\beta_{2}$ for green certificate schemes, as compared to the baseline of a fixed feed-in tariff.

$$
\text { risk } \text { premium }_{i}=\alpha+\beta_{1} F I P+\beta_{2} T G C+X \delta+u_{i}
$$

For each interview-observation $i$, we control for additional factors through explanatory variables contained in $X$. Our additional co-variates include dummies for the implicit stop of renewable support, retrospective changes, tenders and the type of respondent. Retrospective changes play a particularly important role. Some countries have implicitly, if not explicitly, abandoned any support for renewable energies, for instance through the abolition of remuneration payments or network operators stopped grid connections for new wind power plants due to network stability concerns. Where governments have retrospectively changed remuneration, the underlying risks also for new installations may have shifted, resulting in additional renewable energy risk premia. Through such changes, some governments aimed to reduce their own or their constituents' financial obligations to existing projects. We therefore also include information whether such changes have occurred. An additional dimension are tenders. They are potentially implemented on top of the regular policy regime, such that market actors have to participate in tenders in order to be entitled to receive the normal remuneration. The type of respondent - project developer, banker or academic - might also influence the results if these groups have systematically different perceptions of financing parameters.

This simple specification can be estimated using ordinary least squares (OLS). One obvious necessity for this estimator is, though, that the dependent variable consists of individual values, e.g. a risk premium of $5.3 \%$. However, in several interviews (23\%), respondents did not provide point estimates for the financing costs, but ranges with an open upper or lower limit, e.g. "The weighted average cost of capital is less than 5.3 percent". Consequently, in order to run an ordinary least square regression, we have to approximate the exact value they mean. In a first step, we assume the decrease (increase) to be .5 percentage points when the actual number was "slightly lower" (higher), 1 percentage point when it was "lower" (higher), and 1.5 percentage points when it was "much lower" (higher).

\subsection{Results}

The results of our main specification show that feed-in tariffs and sliding premia are associated with the same risk premium for investors, whereas green certificate schemes are associated with significantly higher costs. The differences between feed-in tariffs and sliding feed-in premia are insignificant (see 
column (1) of table 2). Under the feed-in premium, the revenue risk remains as low as under the feed-in tariff, most likely since investors receive the sliding market premium on top of the electricity prices, with a particular, almost certain strike price. It appears that markets evaluate the risks as low as under feed-in tariffs, or that they trust that the regulator would bail-out any stranded assets that might appear due to e.g. the introduction of new price zones. We present an additional regression with all "safe policies" as baseline, feed-in tariff and feed-in premium, shown in column (2). In both estimations (1) and (2), significance of the explanatory variables remains the same.

Most importantly, tradable green certificates are associated with an increase in the risk premium by $1.2-1.3$ percentage points, or $27-33$ percent in the logarithmic specification. This indicates that investors keep some of the power price risk. This is possibly also even the case where they sign long-term contracts with off-takers, as these off-takers might go bankrupt or ask for renegotiations of contracts when spot market prices fall.

Where regulators have implicitly, if not officially, stopped implementing the policy scheme for new installations, financing costs are increased as well. The results indicate they are increased by 2.3 percentage points. One reason for this could be the additional uncertainty with respect to administrative processes and the significant revenue uncertainty. Similarly, in the logarithmic specifications, the coefficients are statistically significant at the 1 percent level, implying an increase in financing costs by almost $50 \%$.

Somewhat surprisingly, retrospective changes have no statistically significant effect on the financing costs. One explanation is that the respondents evaluated their country's situation as if these changes had not taken place.

Furthermore, tenders do not decrease or increase revenue risks if they are implemented on top of the main policies. This means tenders set the price level, but once investors have won them, regular feed-in tariffs/premia apply, i.e. no new revenue risks are induced for investors at that stage. Where financing needs to be secured before the tenders, uncertainty about the tender outcome can still induce risks at such an early stage. The responses from the different types of investors do not differ from one another. Compared to the baseline academic/consultant, neither equity investors, utility employees nor banker gave systematically different replies.

Our results indicate that secure designs of sliding feed-in premia enables such schemes without inducing significant additional revenue risks and thus without additional financing costs, at least on the short term. However, with potentially increasing balancing costs and changes in the power market design, investors might perceive the revenues under feed-in premia as more uncertain, which would lead to increases in financing costs.

Tradable green certificates incur additional risks and hence additional financing costs. Without regulatory off-take guarantees, investors keep some of the revenue uncertainty, such that capital providers require higher returns. This suggests that even where investors sign long-term off-take contracts with private off-takers, some risk remains with them as the off-takers might go bancrupt or alternatively demand renegotiations in case of low power prices.

These results rest on several assumptions. We assume that by controlling for countries' general financing environment, we can control for national factors that influence project financing costs for wind power projects, or that such variations occur randomly across countries. Moreover, we rely on the respondents' 
Table 2: OLS estimation results

\begin{tabular}{lcccc}
\hline & $(1)$ & $(2)$ & $(3)$ & $(4)$ \\
& Level & Level & Log & Log \\
Dep. var: risk premium & & & & \\
\hline Sliding feed-in premium & -0.290 & & -0.176 & \\
& $(0.501)$ & & $(0.187)$ & \\
Tradable green certificates & $1.209^{* *}$ & $1.306^{* *}$ & $0.269^{* *}$ & $0.328^{* * *}$ \\
& $(0.417)$ & $(0.389)$ & $(0.095)$ & $(0.087)$ \\
No policy & $2.274^{* * *}$ & $2.341^{* * *}$ & $0.453^{* * *}$ & $0.494^{* * *}$ \\
& $(0.438)$ & $(0.421)$ & $(0.097)$ & $(0.087)$ \\
Retrosp. changes & -0.139 & -0.082 & -0.048 & -0.013 \\
Tenders & $(0.366)$ & $(0.361)$ & $(0.088)$ & $(0.083)$ \\
& 1.030 & 0.887 & 0.304 & 0.217 \\
Equity investor & $(0.608)$ & $(0.575)$ & $(0.156)$ & $(0.130)$ \\
& -0.266 & -0.293 & -0.048 & -0.065 \\
Utility employee & $(0.323)$ & $(0.320)$ & $(0.080)$ & $(0.074)$ \\
& -0.336 & -0.316 & -0.093 & -0.080 \\
Banker & $(0.539)$ & $(0.528)$ & $(0.126)$ & $(0.118)$ \\
& -0.708 & -0.729 & -0.263 & -0.275 \\
$N$ & $(0.507)$ & $(0.535)$ & $(0.192)$ & $(0.212)$ \\
\hline
\end{tabular}

Robust standard errors in parentheses

${ }^{*} p<0.05,{ }^{* *} p<0.01,{ }^{* * *} p<0.001$

Fixed feed-in tariff and the Belgian and Romanian TGC systems with significant price floors are the baseline policy. In columns 2 and 4, also the feed-in premium is in the baseline. Academic/Consultants are the baseline respondent group.

knowledge of the financing costs in their country. If this knowledge varied with the prevailing policy scheme, the results are biased.

\subsection{Robustness checks}

As robustness check, we can derive the unknown estimates conditional on the known ones, assuming a certain functional form for the distribution of the risk premium estimates. We have a vector of lower boundaries (in case of statements where the upper boundary is open) and a vector of upper boundaries (in case of statements where the lower boundary is open). We assume that the lower (upper) boundaries follow normal distributions, and that the unknown values also adhere to these distributions. Then, a maximum likelihood estimator will be unbiased: the interval regression estimator, which is a generalized censored regression estimator. The unbiasedness of this estimator hinges on two assumptions: First, the lower (upper) estimates need to follow normal distributions. Second, the unknown values have to follow the same normal distribution. We can test only the first of these assumptions. Visual and numerical checks of this assumption state that normality of the known estimates cannot be rejected for a specification in levels. As it is rejected in the logarithmic specification, we prefer the level specification over the logarithmic one. Details on the normality 
assumptions are given in Appendix A.

The results from the interval regression are very similar to the OLS estimates, indicating that neither estimator induces significant biases, and thus confirming the validity of our approach. Table 3 provides an overview of the results for the interval regressions. As argued before, the level specification in columns 1 and 2 are preferred over the logarithmic estimations in columns 3 and 4 . The first estimation indicates that the differences between feed-in tariff and sliding feed-in premium are again insignificant.

Also under the interval regression, tradable green certificates are associated with a 1.2 percentage points higher risk premium at a 1 percent significance level. This is on average equivalent to an increase of the risk premium by almost a third and thus also economically significant. Turning towards the other explanatory variables, their sign and statistical significance are similar to those of the OLS regressions. Where policies have been abolished implicitly, financing costs strongly increase.

Table 3: Interval regression estimation results

\begin{tabular}{lcccc}
\hline & $(1)$ & $(2)$ & $(3)$ & $(4)$ \\
Level & Level & Log & Log \\
Dep. var: risk premium & & & & \\
\hline Sliding feed-in premium & -0.030 & & -0.130 & \\
& $(0.535)$ & & $(0.228)$ & \\
Tradable green certificates & $1.213^{* *}$ & $1.222^{* *}$ & $0.292^{* *}$ & $0.333^{* *}$ \\
& $(0.417)$ & $(0.414)$ & $(0.094)$ & $(0.108)$ \\
No policy & $2.477^{* * *}$ & $2.484^{* * *}$ & $0.528^{* * *}$ & $0.557^{* * *}$ \\
& $(0.458)$ & $(0.451)$ & $(0.105)$ & $(0.110)$ \\
Retrosp. changes & -0.212 & -0.207 & -0.047 & -0.023 \\
& $(0.354)$ & $(0.354)$ & $(0.092)$ & $(0.092)$ \\
Tenders & 0.867 & 0.851 & 0.270 & 0.203 \\
& $(0.604)$ & $(0.534)$ & $(0.177)$ & $(0.125)$ \\
Equity investor & -0.320 & -0.323 & -0.057 & -0.069 \\
& $(0.304)$ & $(0.311)$ & $(0.080)$ & $(0.078)$ \\
Utility employee & -0.369 & -0.366 & -0.122 & -0.107 \\
& $(0.522)$ & $(0.516)$ & $(0.129)$ & $(0.119)$ \\
Banker & -0.592 & -0.592 & -0.229 & -0.230 \\
& $(0.496)$ & $(0.500)$ & $(0.198)$ & $(0.208)$ \\
\hline$N$
\end{tabular}

The interval regression estimator relies on additional assumptions on asymptotic characteristics of the data. Specifically, it assumes that the unknown weighted average cost of capital estimates are distributed according to the normal distributions derived from the known estimates. Yet, especially in the case of the unknown ones, one could argue that they are likely to be outliers as 
compared to the known ones.

Additional robustness checks test how sensitive the OLS specification is to the necessary interpretation of replies, as the unbiasedness of OLS relies on the correct interpretation of these replies. The relevance of this limitation can be identified by comparing the results with different codings. We estimate the regression with different absolute interval interpretations and with relative interpretations, i.e. "slightly lower" (higher) implying 5 percent lower (higher) weighted average cost of capital, 10 percent when it was "lower" (higher), and 20 percent when it was "much lower" (higher). These sensitivity estimates can be found in Appendix B. They support the results of the main analysis, implying that the actual coding-specification has some effect on the magnitude of the point estimates, but does not strongly affect statistical significance, and indicating that no significant bias is introduced by the necessary response interpretations under the OLS specification.

\section{The role of long-term contracts for renewable energy investments}

Long-term contracts play a key role for renewable energy investments under green certificate schemes and fixed premia. Where policy design does not comprise implicit long-term contract, we observe that market participants seek to sign bilateral long-term contracts as basis for project financing of renewable energy projects. The counter-party to the project developer, which we will in the following refer to as off-taker, may incur risks in signing such contracts as the price to which the power is acquired via long-term contract may exceed the price at which the off-taker can sell it in future years to customers. Such risks imply that the off-taker does, even in competitive environments, only offer prices below the expected value of the energy from the renewable project to compensate for its additional costs. This in turn implies that the project needs to obtain additional support to break even and hence directly translates into additional deployment costs. While we focus the subsequent discussion on investments through project finance, the analysis and results holds similarly for vertically-integrated companies, as Finon (2008) describes how long-term contracts between generators and retailers and vertical integration are substitutes to establish the required long-term cash flow security, and Aïd et al. (2011) argue that which construct will prevail depends on the degree of uncertainty.

\subsection{Implications of long-term contracts for private off- takers}

Project investors seek long-term certainty about their revenue streams, commonly more than ten and up to twenty years, in order to secure a high share of debt relative to equity and thus low capital costs for the investment. With such long-term contracts and low variability of project revenues, lenders' revenue requirements lie lower, i.e. the project's financing costs (Markowitz, 1952, Roques et al., 2008). This is particularly important since long-term financial hedging is not available for electricity, unlike for ordinary commodities. It is not storable economically on a long-term, large scale basis and is heterogeneous: its value varies with place and time of generation (Finon, 2011, Roques et al., 2008). 
We quantify the additional risks for the long-term contract's off-taker. This risk is primarily that the off-taker has contracted the power at long-term prices that turn out to be above spot prices. However, as the off-taker cannot sign equivalent long-term contracts with private households for regulatory reasons, and such contracts pose too large obligations for most companies, the off-taker cannot sign corresponding long-term contracts with final customers. Therefore, the off-taker carries the price risk and in a situation with low spot prices incurs losses. ${ }^{5}$

This explains why according to Baringa (2013) and Standard \& Poor's (2017), rating agencies consider long-term contracts exposure of firms in their credit rating by adding the value of the long-term contract to the liabilities of a company, as they in turn cannot sign long-term contracts with household or industry customers under retail competition. Accordingly, an additional longterm contract is equivalent to additional debt and thus increases the debt-equity ratio. The higher debt-equity ratio reduces the credit rating and results in higher default spreads for all debt raised and higher return requirements for equity. ${ }^{6}$

The off-taker will therefore only sign long-term contracts at a discount which in competitive markets reflects the increased financing costs. Project developers will require compensating payments through other channels, e.g. by bidding higher required remuneration levels under fixed premia, or requiring higher green certificate prices.

We approximate the cost incurred by an off-taker in signing a long-term contract. A firm's total capital cost is depicted as $C$ and comprises both the cost for debt $d$ and equity $e$ at the respective return requirements $r_{d e b t}$ and $r_{\text {equity }}$.

$$
c(d, e)=r_{\text {debt }} d+r_{\text {equity }} e
$$

The return requirements depend on the rating grade $g(d, e)$, which is in turn a function of the debt-equity ratio. The total capital costs are thus

$$
c(d, e)=r_{\text {debt }}(g(d, e)) d+r_{\text {equity }} g(d, e) e
$$

Private off-takers' balance sheets change for rating purposes when they sign long-term contracts. The additional long-term liabilities are added to the companies' debt stock, worsening their debt-equity ratio and rating grade. For simplicity, we analyze only the changes in the costs of debt, rendering our estimates a lower bound of the costs of an increase in debt. ${ }^{7}$ Simplifying the notation and introducing the respective partial derivatives $c_{d}^{\prime}(d, e), r_{d e b t_{g}}^{\prime}(g(d, e))$ and $g_{d}^{\prime}(d, e)$, the derivate is:

$$
\frac{\partial c(d, e)}{\partial d}=\frac{\partial r_{d e b t}(g(d, e))}{\partial g} \frac{\partial g(d, e)}{\partial d} d+r_{d e b t}(g(d, e))
$$

\footnotetext{
${ }^{5}$ The off-taker also incurs the risk that the project fails to produce at times when the contract price is below the spot price level.

${ }^{6}$ If rating agencies treat only part of the contract value as liabilities, this reduces the estimated costs. Yet, according to Standard \& Poor's (2017), even companies not object to retail competition and with regulated cost recovery half of the contract value is counted, indicating higher numbers for companies in retail competition.

${ }^{7}$ We are in the following also disregarding that equity might become more expensive, which would increase our cost estimates.
} 


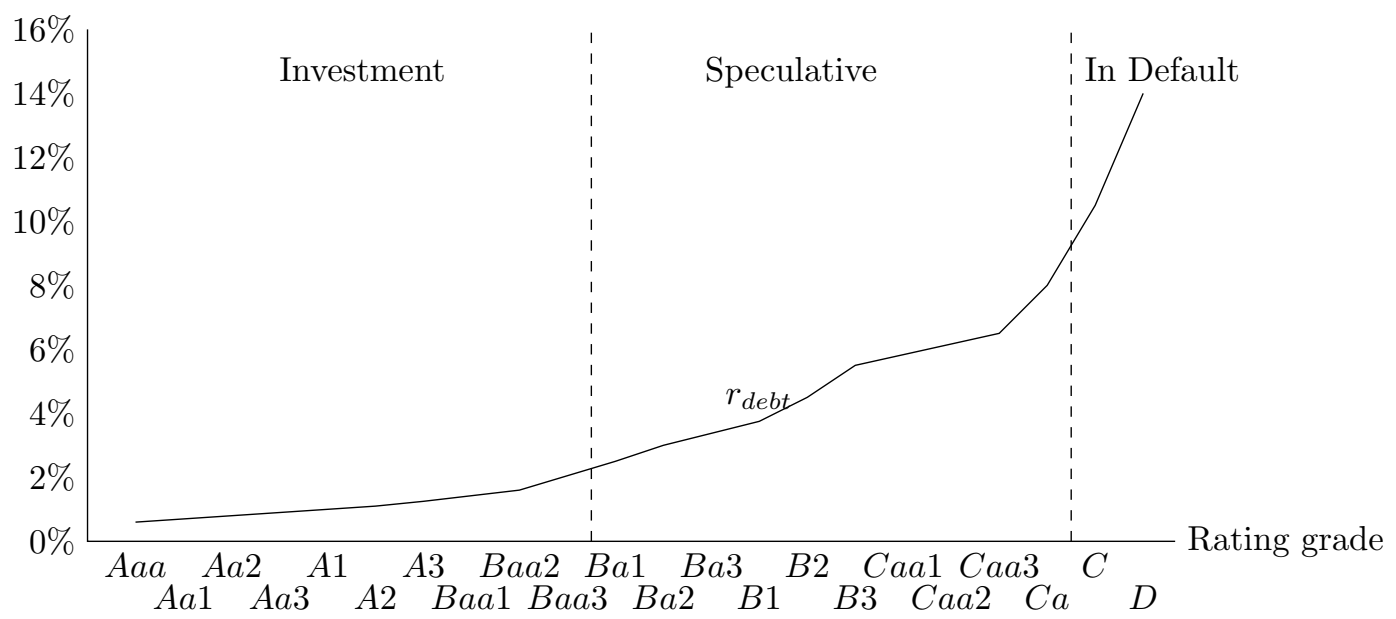

Figure 2: Default spread as function of corporate credit rating, based on Damodaran (2017)

The term $\frac{\partial r_{\text {debt }}(g(d, e))}{\partial g} \frac{\partial g(d, e)}{\partial d} d$ represents the increase in costs caused by the increase in interest rate, as this higher interest rate is in the long run applied to the total stock of debt $d$. The term $r_{\text {debt }}(g(d, e))$ represents the cost of an additional unit of debt and simply equals the interest rate. As described in Standard \& Poor's (2017), the long-term contract is evaluated as imputed debt, i.e. equivalent to an increase in liabilities, and thus impacts the debt-equity ratio, the off-taker does not increase its debt. We therefore omit the term $r_{\text {debt }}(g(d, e))$ in the following.

We analyze how the interest rate responds to an incremental change in credit rating using data provided by Damodaran (2017) for all traded US companies. ${ }^{8}$ Analyzing the link between default spreads and ratings reveals that the default spread function is non-linear in rating: The worse the rating, the stronger the impact of a one step change in the credit rating on the default spread (see figure 2). 9

Moreover, the credit rating itself is approximately a linear function of debt. The data by Damodaran (2017) on the relationship between another key financial metric, the interest coverage ratio, and the credit rating indicates that the rating is roughly linear in interest coverage ratio (and approximately correspondingly in debt-equity ratio). This implies that the distances between the otherwise ordinal rating grades $g$ are approximately equidistant.

\subsection{Estimation of off-takers' costs}

We estimate off-takers' costs of signing long-term contracts by parameterizing equation 12. To derive the default spread based on the credit rating, we parameterize function $r_{d e b t}(g(d, e))$. As argued before, the spread increases approximately exponentially, as confirmed by data by Moody's (2005) and Elton et al.

\footnotetext{
${ }^{8}$ We refer to the rating categories in Moody's nomenclature.

${ }^{9}$ For comparison, appendix $\mathrm{C}$ shows the estimation and results for a linear functional form, which however has a lower r-squared ( $82 \%$ in the linear against $93 \%$ in the quadratic case).
} 
Table 4: Interest rate as quadratic function of traded US companies' credit ratings, based on aggregate data by Damodaran (2017)

\begin{tabular}{ll}
\hline Estimation results & $(1)$ \\
\hline & \\
\hline Dep. var.: $r_{\text {debt }}$ & $0.000231^{* * *}$ \\
$\mathrm{~g}^{2}$ & $(0.0000175)$ \\
& -0.000481 \\
$\mathrm{~m}$ & $(0.00434)$ \\
\hline $\mathrm{N}$ & 15 \\
\hline Robust standard errors in parentheses \\
${ }^{*} \mathrm{p}<0.10,{ }^{* *} \mathrm{p}<0.05,{ }^{* * *} \mathrm{p}<0.010$ & \\
\hline
\end{tabular}

(2001). A respective non-linear function for the default spread $r_{\text {debt }}(g(d, e))^{10}$ is:

$$
r_{\text {debt }}(g(d, e))=m+\lambda g(d, e)^{2}
$$

with slope

$$
\frac{\partial r_{d e b t}(g(d, e))}{\partial g(d, e)}=2 \lambda g(d, e)
$$

We estimate equation 14 with the aggregated by Damodaran (2017). Specifically, we regress the default spread on the according squared rating, using a simple OLS estimator. Following the discussion in section 4, we assume equal distances between the rating grades and codify them as numerical values $n$, with the best rating $A A A$ as 1 , the second best rating $A A 1$ as 2 and so forth. The term $u_{g}$ represents the error term.

$$
r_{\text {debt }}=m+\lambda n_{g}^{2}+u_{g}
$$

The coefficient $\lambda$ is statistically significant and is equal to 0.00023 , while the constant is insignificant, as table 4 shows. The equation describes how the default spread reacts to a change in credit grade. For example, a downgrade by one rating from $\mathrm{Ba} 2$ to $\mathrm{Ba} 3$ results in an increase in default spread from 2.8 to 3.3 percent.

The rating grad $g(d, e)$ is a function of the debt-equity ratio. The function differs between industries, and thus we prefer deriving parameter values from a sample of European utilities. The credit rating function can be expressed as:

$$
g(d, e)=n+\epsilon \frac{d}{e}
$$

where $n$ is a constant and $\epsilon$ the effect of a one unit increase in the debt-equity ratio on the credit grade. The function's derivative with respect to $d$ is:

$$
\frac{\partial g(d, e)}{\partial d}=\frac{\epsilon}{e}
$$

\footnotetext{
${ }^{10} \mathrm{We}$ are estimating a function for the default spread, even though we discussed the interest rate previously. Yet, we are only interested in changes in the default spread, i.e. the slope. The risk-free rate would be contained in the constant, and thus is not relevant for our subsequent analysis.
} 
Table 5: Credit grade as function of debt-equity ratio based on aggregated annual averages of large EU utilities

\begin{tabular}{ll}
\hline Estimation results & $(1)$ \\
\hline & \\
\hline Dep. var.: g & $2.876032^{* * *}$ \\
\hline debt-equity ratio & $(0.5518585)$ \\
& 2.183433 \\
$\mathrm{~m}$ & $(0.7326723)$ \\
\hline $\mathrm{N}$ & 11 \\
\hline Robust standard errors in parentheses & \\
$* \mathrm{p}<0.10,{ }^{* *} \mathrm{p}<0.05, * * * \mathrm{p}<0.010$ & \\
\hline
\end{tabular}

We regress the credit rating on the debt-equity ratio, applying an OLS estimator. We use aggregated annual data on average debt-equity ratios and credit ratings of twelve large European utility companies over 11 years. The term $u_{t}$ represents the error term.

$$
n_{g_{t}}=b+\epsilon\left(\frac{d}{e}\right)_{t}+u_{t}
$$

The slope $\epsilon$ is estimated as 2.88 and the constant $b$ is 2.18 , as shown in figure 5 . Hence, an increase in debt-equity ratio by one is associated with a downgrade of almost three rating grades.

Combined, we can calculate the off-taker's cost of signing a long-term contract and holding it as liability on the balance sheet for a year by inserting the estimated parameters into equation 12.

$$
\frac{\partial c(d, e)}{\partial d}=2 \lambda\left(b+\epsilon \frac{d}{e}\right) \frac{\epsilon}{e} d
$$

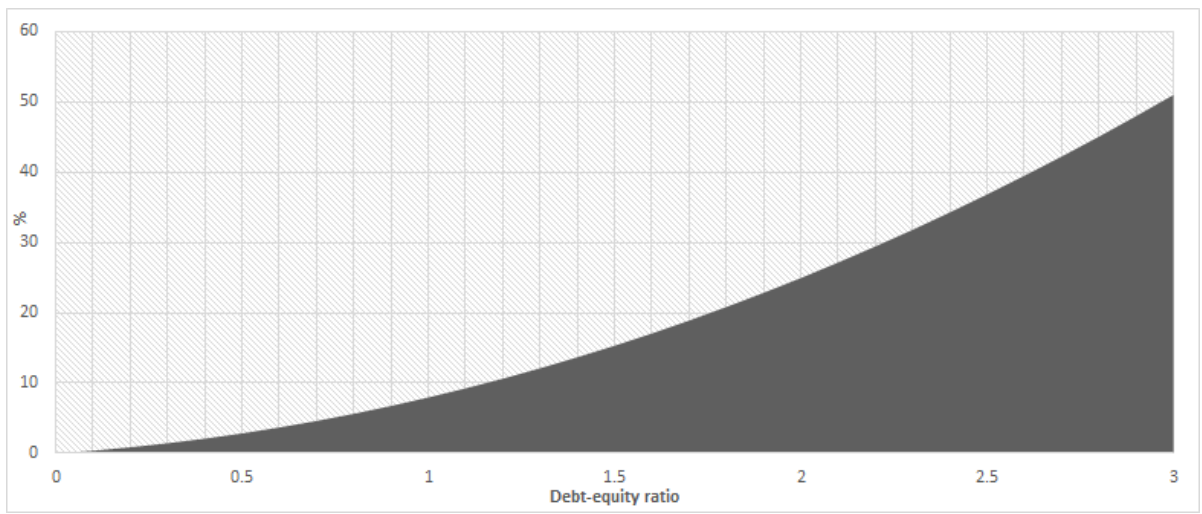

Figure 3: Extra re-financing costs for private off-takers as share of contract value

Based on European utilities' average debt-equity ratio of 2015 of 1.85 , we calculate these annual costs as $1.84 \%$. In order to get the present value of the 


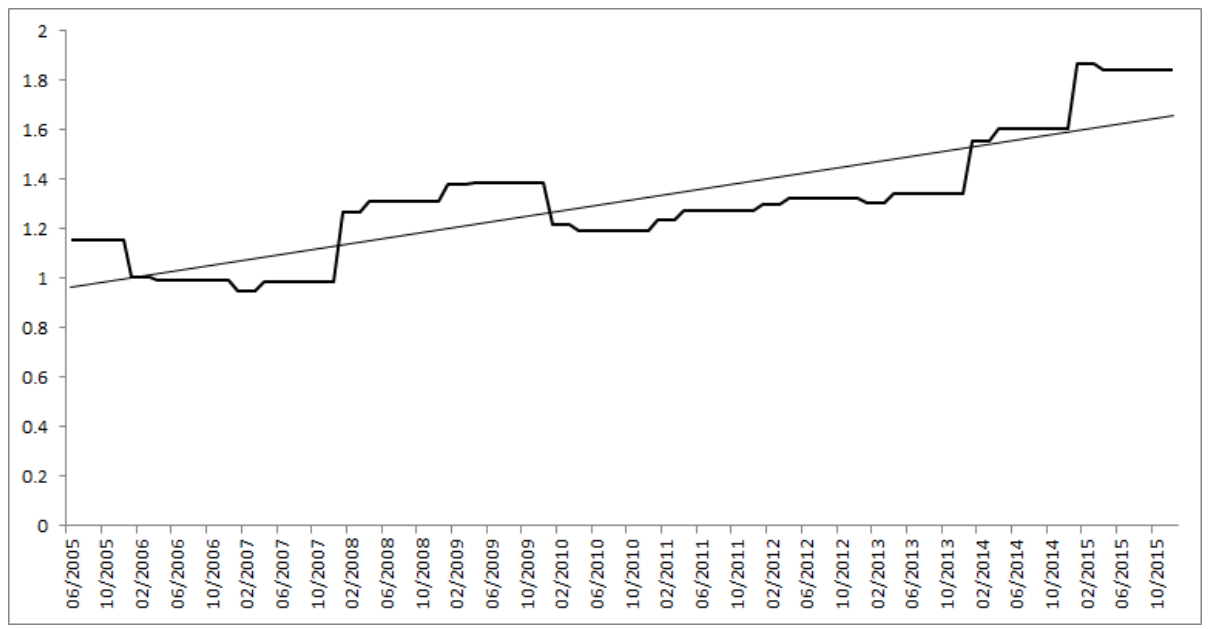

Figure 4: Average debt-equity ratio of twelve large EU utilities. Source: Own calculations based on Datastream International (2016) and Vattenfall (2015)

imputed debt over the contract lifetime, we need to calculate the present value equivalent to the levelizing of the cost of electricity according to equation 13 . The remaining outstanding liabilities decrease every year, as captured in the numerator. For an exemplary lifetime of $T$ of 20 years, the off-taker possesses liabilities for 20 more years in the first year, in the second year for another 19 years, and so forth.

$$
c_{\text {present }}=\frac{\sum_{t=1}^{T} \zeta^{t-1} c_{\text {annual }}(T-t-1)}{\sum_{t=1}^{T} \zeta^{t-1}}
$$

Applying a discount factor $\zeta$ of exemplary $0.96 \%$, the levelized average costs $c_{\text {present }}$ are $21.8 \%$ of the contract value. The costs are depicted in figure 3 across a range of debt-equity ratios of the off-taking company.

These costs lie lower for off-takers in more favorable financial positions: The average debt-equity ratio of the 12 European utilities in 2005 was 1.15 . Inserting this ratio and the parameter values yields a credit rating between A1 and A2 and thus extra costs of $9.9 \%$.

\subsection{Financial position of private counterparties}

In the absence of long-term financial hedges, utilities are the sole market actors that hold relatively stable long-term customer bases, which essentially function as price hedges (Finon, 2011). ${ }^{11}$ Moreover, utilities have traditionally possessed relatively strong financial positions and large portfolios, enabling them to commit to long-term contracts (Baringa, 2013). Consequently, green certificate schemes generally depend on utilities with large sticky customer bases and strong financial positions. However, the subsequent analysis extends to other kinds of companies as well.

\footnotetext{
${ }^{11}$ Sometimes, other companies than utilities aim to obtain renewable electricity directly from investors. In the US in particular, large (IT) companies have thus acted as counterparties to long-term contracts (Bloomberg New Energy Finance, 2016).
} 


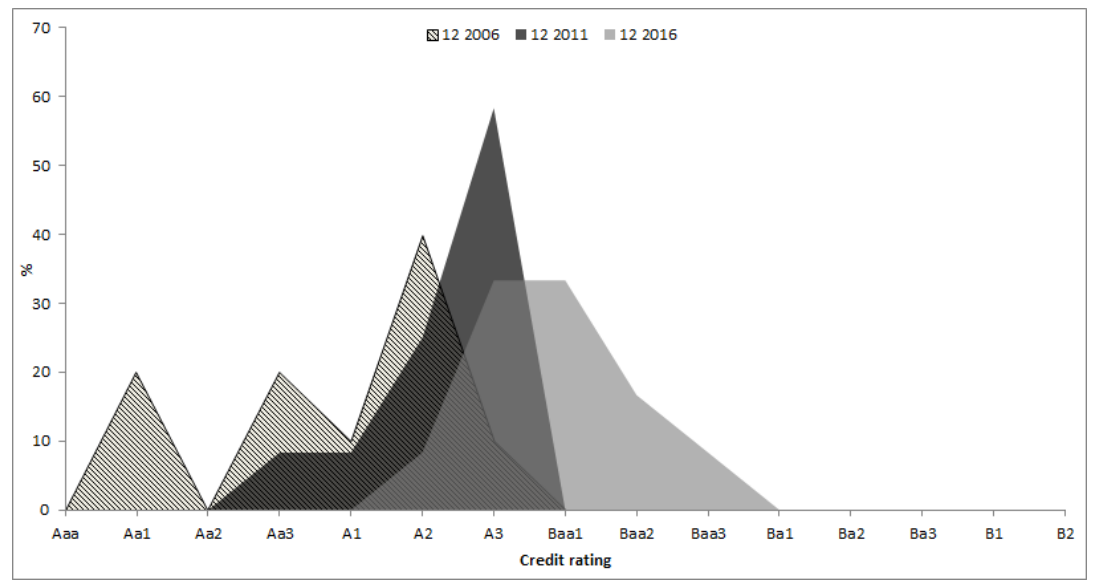

Figure 5: Credit ratings of large EU utilities. Source: Based on Moody's (2017)

Liberalized electricity markets meant new competition on the retail and wholesale markets, and the rise of renewable energies resulted in reduced valuations of conventional power stations, reducing the equity value of companies. Figure 4 visualizes the development of utilities' debt-equity ratios. The average debt-equity ratio of Europe's ten largest utilities, by electricity sales according to RWE (2015), plus British Centrica and SSC has increased strongly between 2005 and 2015: Whereas the average debt-equity ratio stood at 116 percent in June 2005, it has increased to 184 percent by December 2015, an average annual increase of 6.5 percentage points. This is possibly driven by a multitude of factors: Generally falling costs of debt, write-downs on thermal power assets, and the increased competition due to liberalization.

As a result, utilities' credit ratings have worsened. As figure 5 indicates, the respective credit ratings have declined across the board over recent years. On average, bond ratings have fallen more than 2.5 rating categories, e.g. from Aa1 to Aa2 or from A3 to Baa1.

\section{$5 \quad$ Additional costs under green certificate schemes}

Due to regulatory and market risks, green certificates in particular increase the costs of renewable energy deployment. For an exemplary wind power project with levelized costs of electricity of $€ 50$ per MWh under a feed-in tariff, ${ }^{12}$ the current power price pays for about half of the costs, with the other half required as additional support. Under green certificates, the overall costs increase to about $€ 65$ per $\mathrm{MWh}$, increasing the required support (overall remuneration minus power price) by roughly $75 \%$.

This increase stems from both additional regulatory risks, inducing higher financing costs for investors, and market risks, inducing costs for off-takers of long-term contracts. Firstly, incomplete hedging of regulatory risks increase investors' financing costs by about 1.2 percentage points, as identified in section

\footnotetext{
${ }^{12} \mathrm{We}$ apply rather low cost estimates of $€ 1080$ per $\mathrm{kW}$ and $€ 50$ per $\mathrm{kW}$ as operation and maintenance costs combined with a high capacity factor of $33 \%$, based on Deutsche WindGuard (2013), and exemplary $4 \%$ financing costs
} 


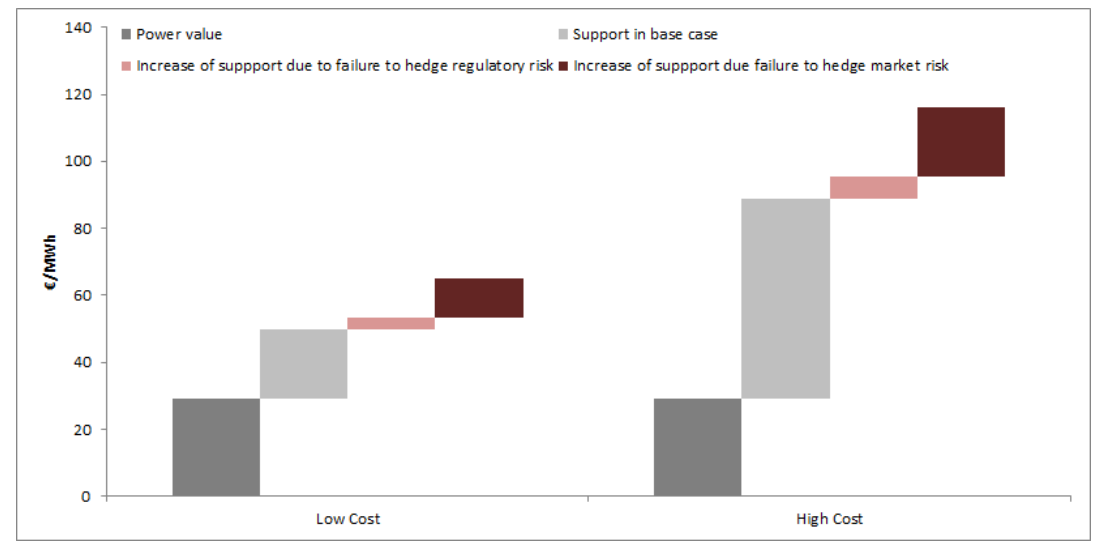

Figure 6: Additional costs under green certificates

3.3. This translates into an increase to $€ 53$ per MWh, as shown in figure 6 . Secondly, the failure to hedge market risks induce higher costs for off-takers of long-term contracts amounting to about $21.8 \%$ of the contract value, as described in section 4 . This translate into a cost increase to $€ 65$ per MWh, equivalent to an increase in investors' financing costs by another 3.6 percentage points. In total, this cost increase is equivalent to an increase in investors' financing costs by 4.8 percentage points.

With higher initial project costs, the additional costs increase proportionally. Initial costs of $€ 89$ per MWh under a feed-in tariff rise to $€ 116$ per MWh under green certificates. ${ }^{13}$ This divides into additional costs of $€ 7$ per MWh for the new regulatory risks and additional costs of $€ 20$ per MWh for the new market risks.

In general, the same extra costs for long-term contracts are introduced when all policy support is abolished and investments are conducted based on a significant carbon price. This price would have to be high enough that the expectation of the resulting power price is sufficient to support investments into renewable energies. Then, investors would still hedge their resulting price risks and thus liabilities, implying similar cost increases.

Under fixed premia, the cost increase applies only to a part of the overall costs of renewable energies. Investors sell their electricity and receive additional, fixed premia, so they only need to sign long-term contracts for the power value, as the premium is guaranteed by the regulator. If, as in the previous example, the power price makes up about half of the total remuneration, the extra costs of $21.8 \%$ thus apply only to this half. The additional costs for the off-takers hence increase the overall costs by slightly more than $10 \%$.

\section{Conclusion}

Power systems with increasing shares of wind and solar generation have high capital and low operational costs. This increases the importance of the cost

\footnotetext{
${ }^{13}$ This scenario grounds on the same cost assumption as previously, but higher investment costs of $€ 1500$ per $\mathrm{kW}$ and a lower capacity factor of $23 \%$.
} 
of finance for total system cost. We estimate how different risk factors affect investors' financing costs.

First, based on a survey on wind power financing cost estimates from EU member states, we find that sliding feed-in premia do not increase financing costs in comparison to fixed feed-in tariffs. Tradable green certificates can be associated with increases in the wind-power risk premium by about 1.2 percentage points. Equity and debt providers require higher risk premia because of the higher revenue variability and the additional default possibility of the long-term contracts' private counterparties. These results hold under ordinary least square specifications as well as with interval regressions, which take into account the specific nature of responses, with several replies in relative terms.

Second, we model the implicit long-term hedge that renewable support mechanisms can offer to market participants. In principle, both renewable project developers and final consumers would like to hedge against price uncertainty. In practice, market design rules and counter-party risks inhibit such long-term contracts with final consumers. In the absence of long-term contracts with final consumers, project developers sign long-term contracts with energy suppliers to secure revenue streams for financing purposes. We estimate, the increase of financing costs energy suppliers incur when accepting the risks involved in signing such long-term contracts. Ultimately these costs are passed to consumers resulting in around $20 \%$ additional cost of renewable energy deployment.

The combined increases in financing costs for the investor and for the private counterparty for long-term contracts render renewable energy deployment about $30 \%$ more expensive under green certificate schemes, increasing costs of an illustrative wind power plant from $€ 50$ per MWh to $€ 65$ per MWh. With increasing shares of renewable energies, and thus higher contracted volumes, this premium is increasing.

Combining the effects of (i) risk for project investors and (ii) risk for counterparties signing long-term off-take contracts may also explain a paradoxon of previous assessments. Studies like Ragwitz et al. (2012) and Butler and Neuhoff (2008) show that significantly higher support levels are required where policy design involves green certificate systems, but no equivalent discrepancy in financing cost has been identified in surveys among investors. Future research could investigate the role of additional dimensions of renewable energy support like preferential public loans or priority dispatch. 


\section{References}

Aïd, René, Gilles Chemla, Arnaud Porchet, and Nizar Touzi. 2011. "Hedging and Vertical Integration in Electricity Markets." Management Science, 57(8): 1438-1452, DOI: http://dx.doi.org/10.1287/mnsc.1110. 1357.

Baringa. 2013. Power Purchase Agreements for independent renewable generators an assessment of existing and future market liquidity. London. Commissioned by the Department of Energy and Climate Change.

Bloomberg New Energy Finance. 2016. Corporate renewable energy procurement. December.

Boomsma, Trine Krogh, and Kristin Linnerud. 2015. "Market and policy risk under different renewable electricity support schemes." Energy, 89(February 2014): 435-448, DOI: http://dx.doi.org/10.1016/j.energy.2015. 05.114.

Bürer, Mary Jean, and Rolf Wüstenhagen. 2009. "Which renewable energy policy is a venture capitalist's best friend? Empirical evidence from a survey of international cleantech investors." Energy Policy, 37(12): 49975006, DOI: http://dx.doi.org/10.1016/j.enpol.2009.06.071.

Butler, Lucy, and Karsten Neuhoff. 2008. "Comparison of feed-in tariff, quota and auction mechanisms to support wind power development." Renewable Energy, 33(8): 1854-1867, DOI: http://dx.doi.org/10.1016/j. renene.2007.10.008

Couture, Toby, and Yves Gagnon. 2010. "An analysis of feed-in tariff remuneration models: Implications for renewable energy investment." Energy Policy, 38(2): 955-965, DOI: http://dx.doi.org/10.1016/j.enpol.2009. 10.047.

Damodaran, Aswath. 2017. Ratings, Interest Coverage Ratios and Default Spread.

Datastream International. 2016. Debt/Equity Ratio. Assessed 24.05.2016.

Deutsche WindGuard. 2013. Kostensituation der Windenergie an Land in Deutschland. Varel.

Diacore. 2015. The impact of risks in renewable investments and the role of smart policies. Ecofys, eclareon, Fraunhofer ISI, EPU-NTUA, LEI and TU Wien.

Elton, Edwin J., Martin J. Gruber, Deepak Agrawal, and Christopher Mann. 2001. "Explaining the rate spread on corporate bonds." Journal of Finance, 56(1): 247-277, DOI: http://dx.doi.org/10.1111/0022-1082. 00324.

Estonian Windpower Association. 2015. Estonian wind energy producers to receive EUR 32.2 mln of support in 2015.

Eurostat. 2017. Long term government bond yields. 
Finon, Dominique. 2008. "Investment risk allocation in decentralised electricity markets. The need of long-term contracts and vertical integration." OPEC Energy Review, 32(2): 150-183, DOI: http://dx.doi.org/10.1111/ j.1753-0237.2008.00148.x.

Finon, Dominique. 2011. "Investment and Competition in Decentralized Electricity Markets: How to overcome market failure by market imperfections?." In Competition, Contracts and Electricity Markets: A New Perspective. Chap. 3.

González, Javier Serrano, and Roberto Lacal Arántegui. 2015. The regulatory framework for wind energy in EU Member States. European Commission, Joint Reserach Centre, Institute for Energy and Transport, DOI: http://dx.doi.org/10.2790/282003.

Haas, Reinhard, Gustav Resch, Christian Panzer, Sebastian Busch, Mario Ragwitz, and Anne Held. 2011. "Efficiency and effectiveness of promotion systems for electricity generation from renewable energy sources - Lessons from EU countries." Energy, 36(4): 2186-2193, DOI: http://dx. doi.org/10.1016/j.energy.2010.06.028.

Joskow, Paul L. 2006. "Competitive electricity markets and investment in new generating capacity."

Kitzing, Lena. 2014. "Risk implications of renewable support instruments: Comparative analysis of feed-in tariffs and premiums using a mean-variance approach." Energy, 64 495-505, DOI: http://dx.doi.org/10.1016/j. energy.2013.10.008.

Klobasa, Marian, Jenny Winkler, Frank Sensfuss, and Mario Ragwitz. 2013. "Market Integration of Renewable Electricity Generation The German Market Premium Model." Energy and Environment, 24(1-2): 127-146.

Markowitz, H. 1952. "Portfolio selection." The Journal of Finance, 7(1): 7791.

May, Nils. 2017. "The impact of wind power support schemes on technology choices." Energy Economics, 65 343-354, DOI: http://dx.doi.org/10. 1016/j.eneco.2017.05.017.

Moody's. 2005. The Relationship between Par Coupon Spreads and Credit Ratings in US Structured Finance. December.

Moody's. 2017. Moody's - credit ratings, research, tools and analysis for the global capital markets.

NERA. 2013. Hurdle rates change UK. London, commissioned by the Department of Energy and Climate Change.

Newbery, David. 2016. "Policies for decarbonizing a liberalized power sector." EPRG Working Paper 1607, Cambridge Working Paper in Economics 1614. 
Ragwitz, Mario, Simone Steinhilber, Barbara Breitschopf, Gustav Resch, Christian Panzer, Andre Ortner, Sebastian Busch, Karsten Neuhoff, Rodney Boyd, Martin Junginger, Ric Hoefnagels, Jitske Burgers, Maroeska Boots, Inga Konstantinaviciute, and Botond Weöres. 2012. RE-Shaping: Shaping an effective and efficient European renewable energy market.(February): 124.

REN21. 2016. Renewables 2016: Global Status Report. Paris.

Res Legal. 2014. Renewable energy policy data base and support. eclareon. http://www.res-legal.eu.

Roques, Fabien A., David M. Newbery, and William J. Nuttall. 2008. "Fuel mix diversification incentives in liberalized electricity markets: A MeanVariance Portfolio theory approach." Energy Economics, 30(4): 1831-1849, DOI: http://dx.doi.org/10.1016/j.eneco.2007.11.008.

RWE. 2015. Facts and Figures. November. Essen.

Schmalensee, Richard. 2012. "Evaluating policies to increase electricity generation from renewable energy." Review of Environmental Economics and Policy, 6(1): 45-64, DOI: http://dx.doi.org/10.1093/reep/rer020.

Shapiro, S S, and M B Wilk. 1965. "An Analysis of Variance Test for Normality (Complete Samples)." Biometrika, 52(3/4): 591-611, DOI: http: //dx.doi.org/10.1093/biomet/52.3-4.591.

Standard \& Poor's. 2017. "Key Credit Factors For The Regulated Utilities Industry." (61): 1-23.

Tisdale, Matthew, Thilo Grau, and Karsten Neuhoff. 2014. "EEG Reform Impact on Wind Generator Project Finance." DIW Berlin Discussion Paper \#138\%.

Vattenfall. 2015. Vattenfall Annual and Sustainability Report 2015. Stockholm. 

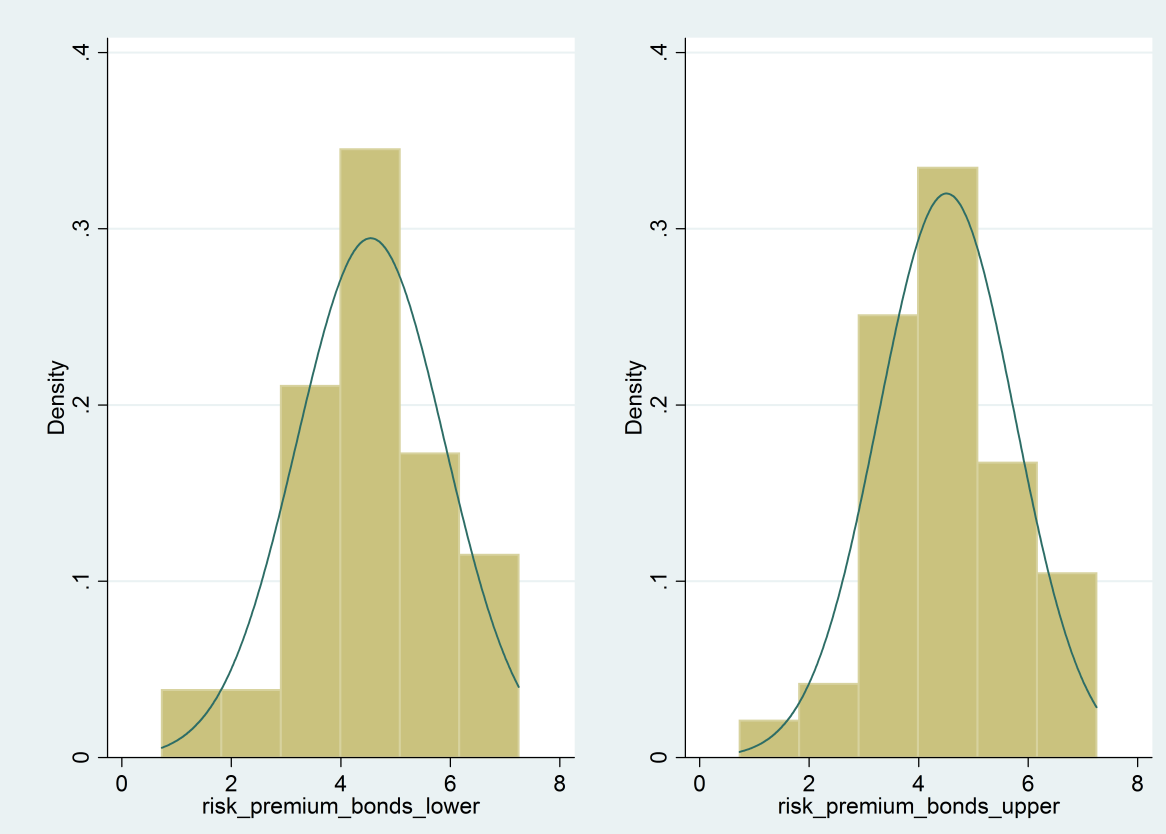

Figure 7: Normality assumption for lower and upper estimates of risk premium in levels

\section{A Normality of weighted average cost of capital estimates}

A rough initial visual check of this assumption can be made by plotting the existing responses against normal distributions, and evaluating if the data appears to adhere to the distribution. Figure 7 shows the risk premium in levels, figure 8 shows it in logarithms. The level specification appears like a better match, as the data is less skewed towards a very narrow interval and has less outliers.

Numerically, we check normality through a Shapiro-Wilk test. It tests the null hypothesis that certain data is normally-distributed (Shapiro and Wilk, 1965). The test of the lower bound yields a $\mathrm{W}$-value of 0.954 , with a resulting p-value of 0.0578 . Hence, the null hypothesis cannot be discarded at a $5 \%$ significance level, yet is rejected on a $10 \%$ significance level. The respective test of the upper bound yields a $\mathrm{W}$ value of 0.963 and a p-value of 0.161 . Thus, we cannot reject the null hypothesis of a normal distribution for the upper bound. Summarizing, some doubts remain with respect to the normality of the lower risk premium boundary, whereas the upper boundary appears normally distributed.

The same tests for the logarithm of the risk premium clearly reject the null hypotheses of normality: The lower boundary's W-value is 0.719 , with a p-value of 0.000 . The upper boundary's W-value is 0.776 , with a resulting p-value of 0.000 . Hence, we prefer the levels-estimation over the log-specification, as the latter will be biased. 

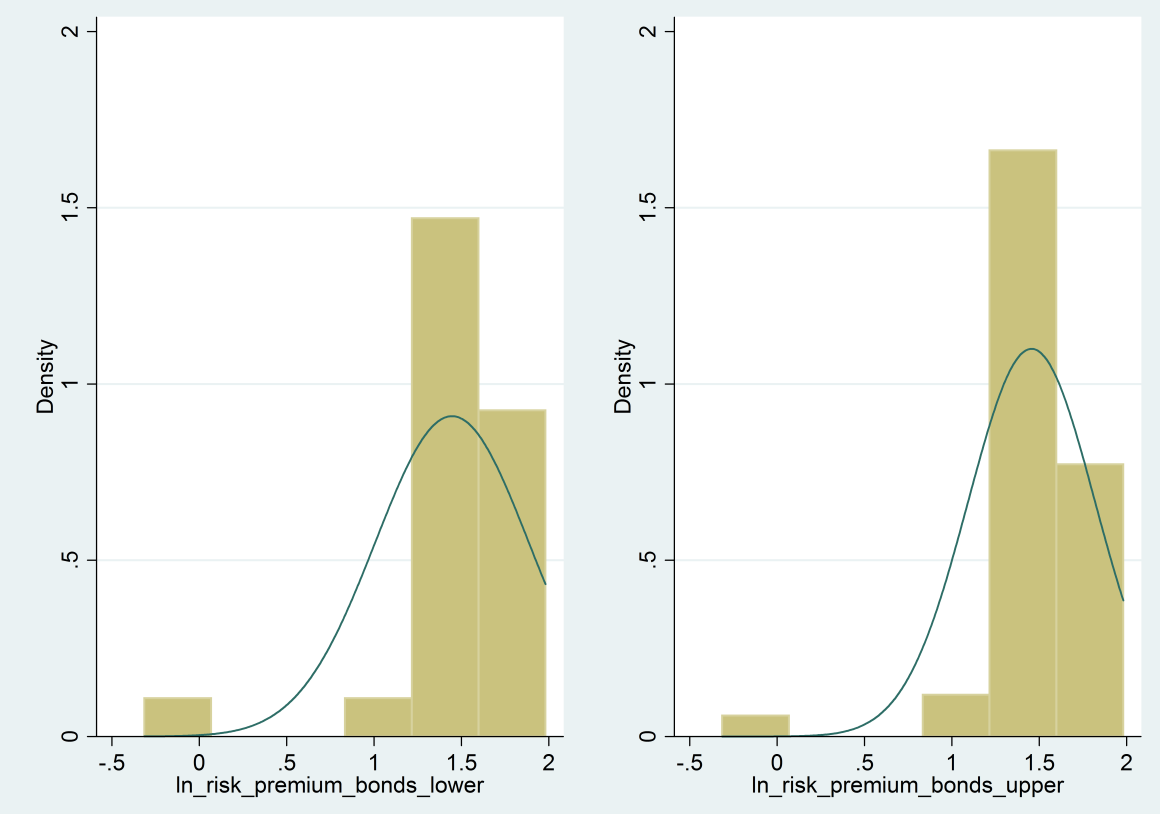

Figure 8: Normality assumption for lower and upper estimates of risk premium in $\log s$

\section{B Sensitivity analyses regarding the coding of responses}

The interview replies are interpreted in some cases where the replies do not yield a point estimate, but rather ranges above or below a certain threshold. Consequently, for OLS regressions, we have to assume what interviewees possibly meant. In the baseline scenario, we count "slightly higher" as 0.5 percentage points higher, "higher" as 1.0 percentage point, and "much higher" as 1.5 percentage points. In the first sensitivity, we change these interpretations to 1,2 and 3 percentage points, respectively. Table 6 shows the results. Statistical significances are the same as previously. The only relevant difference is that the effect of green certificates is even more pronounced: They are associated with an increase of financing costs of 1.6-1.7 percentage points.

Another interpretation of the responses is in relative terms: "slightly higher" implies a 5 percent higher value, "higher" 10 percent, and "much higher" 20 percent. Table 7 yields the results. Statistical significances are the same as before. However, tradable green certificates are only significant at the 5 percent significance level. Their coefficient is also slightly smaller and lies at 1.1-1.2 in the levels-specification, implying an increase in financing costs by 1.1-1.2 percentage points. 
Table 6: OLS estimation results w. alternative coding

\begin{tabular}{lcccc}
\hline & $\begin{array}{c}(1) \\
\text { Level }\end{array}$ & $\begin{array}{c}(2) \\
\text { Level }\end{array}$ & $\begin{array}{c}(3) \\
\text { Log }\end{array}$ & $\begin{array}{c}(4) \\
\text { Log }\end{array}$ \\
Dep. var: risk premium & & & & \\
\hline Sliding feed-in premium & -0.467 & & -0.241 & \\
& $(0.599)$ & & $(0.225)$ & \\
Tradable green certificates & $1.585^{* *}$ & $1.741^{* *}$ & $0.372^{* *}$ & $0.453^{* * *}$ \\
& $(0.533)$ & $(0.507)$ & $(0.125)$ & $(0.119)$ \\
No policy & $2.622^{* * *}$ & $2.729^{* * *}$ & $0.568^{* * *}$ & $0.623^{* * *}$ \\
& $(0.591)$ & $(0.572)$ & $(0.146)$ & $(0.140)$ \\
Retrosp. changes & 0.033 & 0.125 & -0.027 & 0.021 \\
& $(0.559)$ & $(0.569)$ & $(0.147)$ & $(0.148)$ \\
Tenders & 1.214 & 0.984 & $0.415^{*}$ & 0.296 \\
& $(0.677)$ & $(0.634)$ & $(0.187)$ & $(0.149)$ \\
Equity investor & -0.377 & -0.421 & -0.095 & -0.118 \\
& $(0.473)$ & $(0.467)$ & $(0.128)$ & $(0.125)$ \\
Utility employee & -0.552 & -0.519 & -0.144 & -0.128 \\
& $(0.613)$ & $(0.605)$ & $(0.159)$ & $(0.156)$ \\
Banker & -0.567 & -0.601 & -0.159 & -0.176 \\
& $(0.534)$ & $(0.556)$ & $(0.194)$ & $(0.212)$ \\
\hline$N$ & 53 & 53 & 53 & 53 \\
\hline Robust standard errors in parentheses & & & \\
$* * 0.05, * *$ \\
$*$
\end{tabular}

\section{Functional form of the interest rate function}

Assuming a linear functional form for the interest rate function $r_{d e b t_{g}}$, we formulate the following function:

$$
r_{\text {debt }}(g(d, e))=m+\lambda g(d, e)
$$

with slope

$$
\frac{\partial r_{d e b t}(g(d, e))}{\partial g(d, e)}=\lambda
$$

Equivalent to the previous estimation, we estimate:

$$
r_{\text {debt }_{g}}=m+\lambda n_{g}+u_{g}
$$

In this case, the constant is -.0208 and the slope is 0.0052 , as depicted in 8 .

The additional costs for long-term contracts under green certificates differ accordingly, as depicted in figure 9. Using the exemplary cost parameters laid out in section 5 , an installation based on the average debt-equity ratio of the large EU utilities of 1.85 sees additional costs of about $33.4 \%$, i.e. considerably 
Table 7: OLS estimation results w. alternative coding II

\begin{tabular}{lcccc}
\hline & $(1)$ & $(2)$ & $(3)$ & $(4)$ \\
Level & Level & Log & Log \\
Dep. var: risk premium & & & & \\
\hline Sliding feed-in premium & -0.380 & & -0.231 & \\
& $(0.516)$ & & $(0.203)$ & \\
Tradable green certificates & $1.122^{*}$ & $1.249^{* *}$ & $0.242^{*}$ & $0.319^{* *}$ \\
& $(0.434)$ & $(0.402)$ & $(0.100)$ & $(0.092)$ \\
No policy & $2.052^{* * *}$ & $2.140^{* * *}$ & $0.406^{* * *}$ & $0.460^{* * *}$ \\
& $(0.495)$ & $(0.472)$ & $(0.109)$ & $(0.098)$ \\
Retrosp. changes & -0.072 & 0.003 & -0.056 & -0.010 \\
& $(0.453)$ & $(0.455)$ & $(0.105)$ & $(0.102)$ \\
Tenders & 1.012 & 0.824 & 0.320 & 0.206 \\
& $(0.628)$ & $(0.606)$ & $(0.168)$ & $(0.137)$ \\
Equity investor & -0.106 & -0.141 & -0.004 & -0.025 \\
& $(0.376)$ & $(0.369)$ & $(0.088)$ & $(0.081)$ \\
Utility employee & -0.267 & -0.241 & -0.079 & -0.063 \\
& $(0.547)$ & $(0.534)$ & $(0.131)$ & $(0.119)$ \\
Banker & -0.764 & -0.791 & -0.317 & -0.333 \\
& $(0.544)$ & $(0.580)$ & $(0.214)$ & $(0.241)$ \\
\hline$N$
\end{tabular}

Table 8: Interest rate as linear function of traded US companies' credit ratings, based on aggregate data by Damodaran (2017)

\begin{tabular}{ll}
\hline Estimation results & $(1)$ \\
\hline & \\
\hline $\mathrm{g}$ & $0.0052989^{* * *}$ \\
& $(0.0009123)$ \\
$\mathrm{m}$ & $-0.02087331^{* *}$ \\
& $(0.0096336)$ \\
\hline $\mathrm{N}$ & 15 \\
\hline Robust standard errors in parentheses $r_{\text {debt }}$ & \\
${ }^{*} \mathrm{p}<0.10, * * \mathrm{p}<0.05,{ }^{* * *} \mathrm{p}<0.010$ & \\
\hline
\end{tabular}




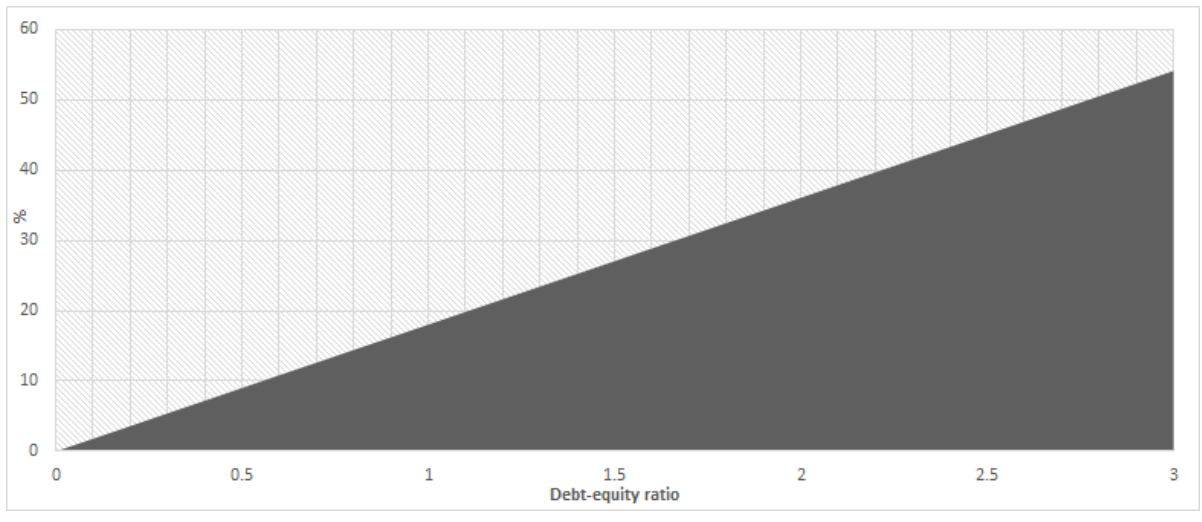

Figure 9: Extra re-financing costs for private off-takers as share of contract value with linear interest rate

more than in the quadratic case. With worse debt-equity ratios, the costs under the quadratic functional form increase more sharply.

\section{Acknowledgements}

We thank Robert Brückmann, Olga Chiappinelli, Ingmar Jürgens, Nolan Ritter, Marie Therese von Schickfus, Bjarne Steffen, Oliver Tietjen and Vera Zipperer for their helpful comments and suggestions. We also benefited from comments by participants at the 11th Conference on The Economics of Energy and Climate Change at the Toulouse School of Economics, the 23rd EAERE conference, the 12th AURÖ workshop, the 5th International Symposium on Environment and Energy Finance Issues, the 39th conference of the International Association for Energy Economics, a seminar at UCL London, and internal seminars at DIW Berlin. 